\title{
Several Factors Influence the Selection of the Companies Accounting Methods
}

\author{
Afrizal \\ Faculty of Economics and Business of Jambi University \\ E-mail: afrizaldoktor@unja.ac.id and afrizaldoktor@gmail.com \\ Susfa Yetti \\ Faculty of Economics and Business of Jambi University \\ E-mail: susfayetti@gmail.com
}

\begin{abstract}
This study aims to find out the several factors influence the selection of The Companies accounting methods. The results showed: (1) Total assets of the companies, DER and bonus managers simultaneously had a significant influence on the selection of Accounting Methods This was supported by Nagel R Square of 0.602 or it could be interpreted that the model could give an influence to change variations of the selection of accounting methods by $60,20 \%$. (2) The debt of the companies which is represented by debt to equity ratio has a significant influence on the selection of Accounting Methods. It means that the greater the company's debt, the greater the tendency of the company to select the accounting methods (3) The companies that have a bonus managers have significant influence on the selection of the Accounting Method, this is supported by the Wald test value is 59,356>2 or pvalue $0,00<$ alpha 0,05 . This means that the greater the bonus manager of the company, the greater the tendency of the company to select accounting methods.
\end{abstract}

Keywords: Asset, debt to equity ratio, and accounting methods.

DOI: $10.7176 /$ RJFA/10-16-14

Publication date: August $31^{\text {st }} 2019$

\section{INTRODUCTION}

\subsection{Research Background}

A research on Accounting always related to how the companies report their financial activities. The tendency of such research will help the owners and creditors to understand the company's fanincial condition. The academic accounting community influences the development of accounting through research. Research in the field of accounting now has various variations and directions. According to Wolk, Francis, and Tearney (1993) the direction of accounting research can basically be grouped into 5 approaches, namely: (1) decision-model approach, (2) capital market research, (3) Behavioural research, (4) Agency theory, and (5) Information economics.

Positive accounting research that developed a lot at this time, mostly based on agency theory. Agency relationship occurs through a contract between one or more owners (principal) and a manager (agent) to carry out the work of the company by delegating some authority of decision making to the agent (Jensen and Meckling, 1976). Management as the one who carries out decision making in the company and as the person responsible for preparing financial data, and it certainly influences how accounting practices are implemented. Decision makers are usually in choosing certain alternative actions based on their want and preferences.

According to the theory there are several accounting methods that can increase corporate reported earnings, and some of those are not. Thus, companies have different motives in selecting the accounting method they do.

Bonus is one of the factors that can influence managers in determining the selection of the use of an accounting method. Big companies also have a tendency to select accounting methods according to what their needs and so to Companies with big of debts.

From the explanation above, it can be seen that the complexity of selecting an accounting method depends very much on the motivation and needs of the companies.

If it is associated to the object of the company for research, it would be more interesting to examine the company which is matching to the type of business, and also, for the case in Indonesia, it would be even more interesting if what are being studied are companies that have gone public. It is because companies that have gone public are mostly the best big companies in Indonesia. In addition, the company's financial statements that have gone public will be read and used by most interested parties.

Generally accepted accounting principles or Indonesian SAK provide alternatives of accounting methods that can be selected by companies to use in their financial reporting or reported earnings.. For manufacturing companies, there are several accounting methods offered, including; inventory method consisting of 3 alternative selections of accounting method, depreciation method consisting of 8 selections of accounting method, and capitalization method consisting of 3 alternative selections of accounting method.

Indonesia Stock Exchange (IDX) has grown rapidly in the past ten years, as seen from the number of 
companies that go public, or companies listed on the IDX to sell their shares. In 1987, it was only 24 listed companies sold their shares, and by the end of 2018, the company that had registered was 633 companies and parts of them are manufacturing companies.

From the above research background, it appears that the principal study in this research is financial accounting using an approach of positive accounting research in which it is also based on the agency theory.

\subsection{Research Problems}

Based on the above research background, the research problem can be formulated as follows:

1) What is the influence of the company's total assets, the company's capital structure, and the bonus mangers (simultaneously) on the selection of the company's accounting methods?

2) What is the influence of th company's total assets, company's capital structure, and the bonus managers (partially) on the selection of the company's accounting methods?

\subsection{Research Objectives}

The purpose of this study is to obtain empirical evidence and to find clarity on the factors influencing companies in selecting accounting methods. The purposes of this study in more detail are to:

1) To analyze the influence of the company's total assets, the company's capital structure, and the bonus managers (simultaneously) on the selection of the company's accounting methods.

2) To analyze the influence of th company's total assets, company's capital structure, and the bonus managers (partially) on the selection of the company's accounting methods.

\subsection{Research Contribution}

The results of this study are expected to provide 2 main contributions, namely:

1) Operational. It is expected that the information can be useful for the users of companies financial statements.

2) Science Development. It is hoped to be able to contribute in the development of accounting science in Indonesia.

\section{LITERATURE REVIEW}

\subsection{Agency Theory}

Schroeder, Clark, and McCullers (1991) define agency as a relationship through agreement between two parties, 1 side, a manager acts as an agent, and onother side, the owner acts as the principal, for example, the relationship between shareholders and the managers of their company which is an agency relationship,

In agency theory, botht he principal and agent are assumed to be rational economic people they are trying to maximize their own utilities. The owner (we call it principal) wants a investment with a good return, meanwhile the managers (agents) want to increase their wealth by getting bonus.

\subsection{Accounting Method}

The accounting methods that are generally used by companies which are on an accounting basis including to manufacturing companies are inventory accounting methods, depreciation accounting methods, and capitalization accounting methods. Other accounting methods are not mentioned above are classified as specific accounting methods according to the business type.

In line with the understanding of the accounting method, it is the procedures for carrying out accounting principles. Selections of using accounting methods are common things to be done, it is meaning that these actions are common as long as the selections are made in accordance with applicable financial accounting standards (SAK).

The existed numbers reported in the financial statements are generally influenced by several factors as shown in the following figure: 


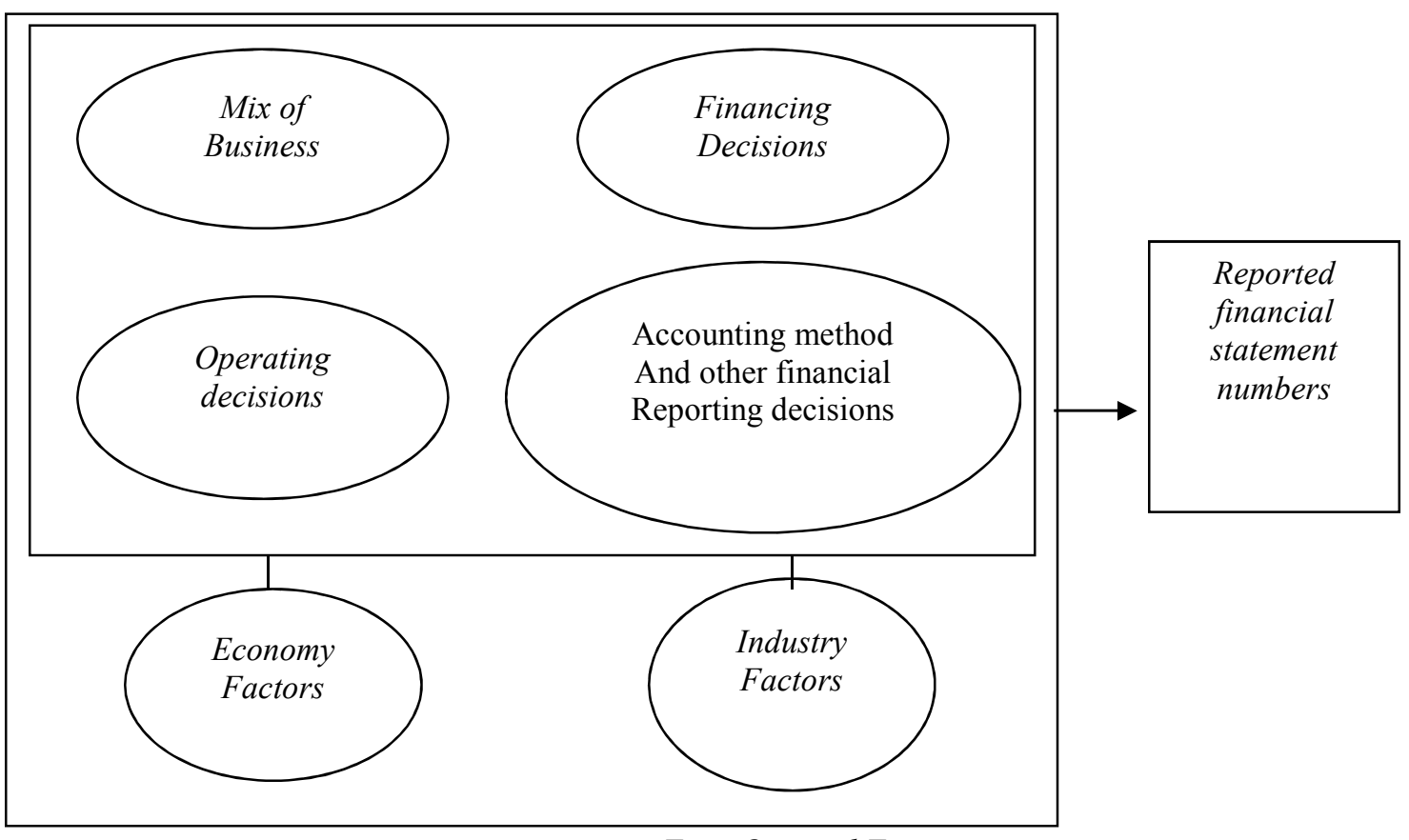

Figure. 01. Interactive Perspective of Accounting Method Selection

Firm-Oriented Factors

(Source: Foster, 1986)

The figure above shows that the numbers in a company's financial statements can be influenced by: business mix, operational decision making, general economic factors, company spending decisions, industry factors, and decision making on the selection of accounting methods used. That Foster's opinion showed that the use of accounting methods is one factor that also determines the numbers in the company's financial statements.

\subsubsection{Inventory Accounting Method}

The term of Inventory is goods held for sale in the normal condition of a company. In the case of manufacturing companies, the inventory also includes goods that are in the process of production or that will be included in the production process.

From the definition of inventory above, it can be concluded that inventory is goods intended for sale in the normal condition of a company operation, and what is also included in inventory are raw materials that will be used for production, raw materials that are in the process of production, and raw materials that have been finished being produced which is ready for sale.

\subsubsection{Capitalization Accounting Method}

The decision whether an expenditure is to be capitalized or to become expensed requires considerations. If an expenditure will provide benefits for the coming period then the expenditure is must be capitalized or used as an asset. If an expenditure only provides benefits in the current period, then the expenditure will be an expense in that period.

\subsection{Decision Making}

Making a selection between two or more alternatives is a decision. before a decision is taken by an individual or by a manager in the company, of course, there is a process, and the process is a decision-making process.

\subsection{Company's Total Asset.}

Total assets, is the total assets owned by the company at a certain time. Sales volume, is the volume of sales of a company in a certain period, for example. The fact that the big companies prefer to select alternative accounting methods that can minimize their profit. Conversely, small companies are often interested in selecting accounting methods that provide greater or higher their profit.

\subsection{Capital Structure}

The capital structure used in this study is Debt to Equity Ratio (DER) which is the relationship between long-term debt and it owner's capital, like this formula:

DER $=$ ratio of Long-term Debt to Owner's Capital

The behaviour of the company's management relating to the selection of accounting methods is also influenced by the company's capital structure, this is due to the limitations in the credit agreement between the 
companies and its bankers or creditors.

\subsection{Bonus Managers}

Bonus are an important mechanism for encouraging and motivating managers to achieve organizational goals. In order for managers to act in the best interests of the company, the owner proposes a bonus plan allowing top manager to take part in increasing the company's wealth. This bonus plan can be in the form of giving stock options or bonuses based on company performance reports. The existence of a manager's bonus plan is very important in order to encourage managers to act in the best interests of the company.

\subsection{Selection of Accounting Methods}

The selection of accounting methods to be used by the company is one of the tasks which is the responsibility of the company's management.

Theoretically reviewed, the selection of accounting methods that are considered good is which method is the most able to bring together income and expenses (matching cost and revenue). In practice, the selection of accounting methods tends not to be based on the concept of matching costs and revenue but is driven more by the motives of different managers. Different managers' motives in selecting alternative accounting methods will cause the selected accounting methods to be different, for example: there are managers who have the desire to increase earnings and in certain conditions there are managers who wish to reduce earnings.

\subsection{Research Framework and Hypothesis}

Starting from the determinat facors, a flow paradigm is prepared such as Figure 02 below:

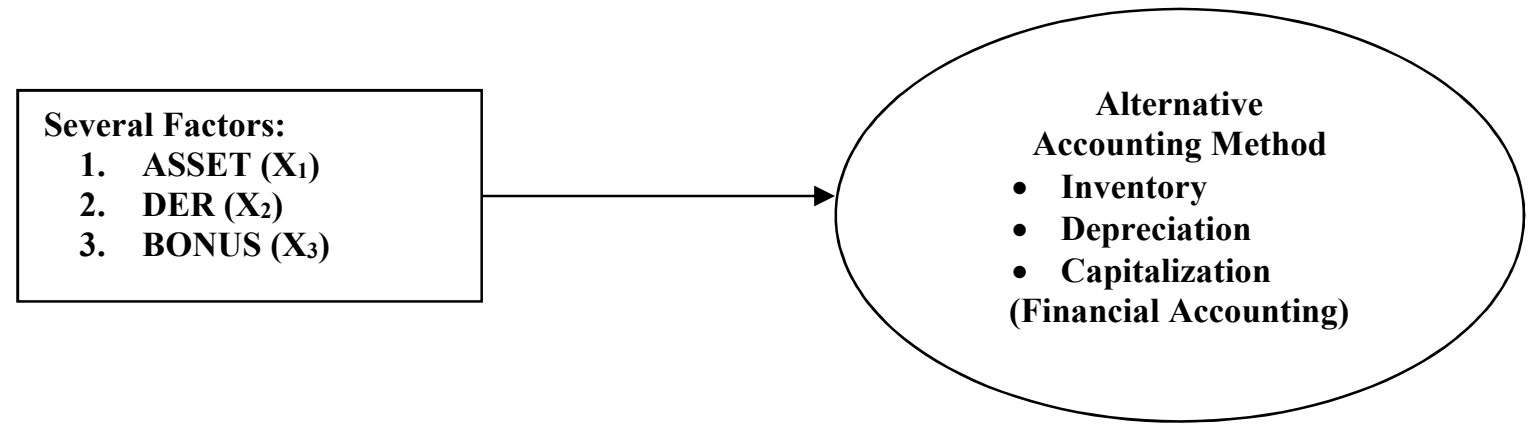

Figure.02. Paradigm of Research Framework

From the research paradigm above, the mathematical equation model can be formulated as follows:

$$
\mathrm{Y}=f\left(\mathrm{X}_{1}, \mathrm{X}_{2}, \mathrm{X}_{3}, \varepsilon\right)
$$

\subsection{Hypothesis}

Starting from the problems and the research framework can be deduced hypothesis as follows:

1) The company's total assets, the company's capital structure, and the bonus managers (simultaneously) influence significantly on the selection of the company's accounting methods.

2) The company's total assets, company's capital structure, and the bonus managers (partially) influence significantly on the selection of the company's accounting methods

\section{RESEARCH METHOD}

\subsection{Research Object}

The object of this research is manufacturing companies listed on the Indonesia Stock Exchange (IDX) for the 2018 period. The number of manufacturing companies registered or that have gone public on the IDX is 127 manufacturing companies.

\subsection{Research Method}

In this study, the research method used is the survey method, which is collecting data (information) from several companies included in the research object. Data collection is carried out using Questionnaire. While, the data used are primary and secondary data, that is, both directly taken from company as the object of research and data from other relevant institutions.

\subsection{Population and Sample}

The population of this study is industry companies listed on the Public List of the Indonesia Stock Exchange (IDX) until the end of 2018 in which there are 164 manufacturing companies. While the sample of this study used a 
purposive sampling method (meaning; the samples selected according to criteria established and needed for the purpose of this study). From the 164 manufacturing companies, it was selected to be samples 127 manufacturing companies.

\subsection{Operationalization of Variables}

The independent variables discussed in the study are limited to four main variables: total asset variable $\left(\mathrm{X}_{1}\right)$, Debt to Equity ratio or DER variable $\left(\mathrm{X}_{2}\right)$, and bonus managers variable $\left(\mathrm{X}_{3}\right)$.

The dependent variable of this study only one variable, namely the accounting method variable (Y).

(1) Company Total Asset $\left(X_{1}\right)$

The scale of the company is measured by measuring tools as follows:

Total assets (in rupiah) as of December 31, 2018. Symbolized with $\mathrm{X}_{1}$

(2) Capital Structure Variable or Leverage. $\left(\mathbf{X}_{2}\right)$

The capital structure variable in this study is the ratio of long-term debt to equity or the ratio of long-term debt to equity. it is also known as Debt to Equity Ratio (DER).

(3) Bonus Managers $\left(\mathbf{X}_{3}\right)$

The manager bonus is determined through a contract between the owner and managers and calculated based on earnings (profits) obtained by the company.

In this study, the intended bonus is an agreement to get a bonus at the end of the year to Top Manager/President Director/Principal Director which is a reward for his success in achieving certain targets.

\section{(4) Accounting Methods Variable (Y)}

Accounting methods are procedures is used for implementing accounting principles to prepare financial statement. The writer realizes that the current accounting methods in Indonesia are numerous. There are accounting methods that can be generally applied to all companies, and there are also accounting methods that can only be applied to certain types of companies.

\subsection{Data Analysis Method}

In this study, quantitative analysis methods are used. Both descriptively and inferentially. Descriptive analysis is done by making a direct tabulation of the data of the variables to be analyzed, then comparing the percentage values and the average. Furthermore, inferential analysis to see the influence of independent variables on the accounting method used Multiple Logistic Regression Analysis because of its conformity with the measurement scale of the independent variables and the measurement scale of the accounting method. The selection of multiple logistic regression or logit model is considered suitable because the dependent variable of this study is nominal or dichotomic. In addition, multiple logistic regression is quite widely used by researchers in the selection of previous accounting methods.

1. To determine the influence of total assets $\left(\mathrm{X}_{1}\right)$, capital structure of the company $\left(\mathrm{X}_{2}\right)$, bonus manager $(\mathrm{X})$ to The accounting method (Y) the model are as follows:

a. Logistics transformation:

$\operatorname{Logit} P(Y)=\beta_{0}+\beta_{1} X_{1}+\beta_{2} X_{2}+\beta_{3} X_{3}+\varepsilon_{i}$

b. The logistic regression model:

$$
P(Y)=1 /\left\{1+\exp \left[-\left(\beta_{o}+\beta_{1} X_{1}+\beta_{2} X_{2}+\beta_{3} X_{3}\right)\right]\right\}
$$

2. To find out the influence of total asset, capital structure, and bonus managers (individually) on the accounting method, the model are as follows:

$\mathrm{P}(\mathrm{Y})=1 /\left\{1+\exp \left[-\left(\beta_{\mathrm{o}}+\beta_{1} \mathrm{X}_{1}+\varepsilon_{\mathrm{i}}\right)\right]\right\}$

$\mathrm{P}(\mathrm{Y})=1 /\left\{1+\exp \left[-\left(\beta_{\mathrm{o}}+\beta_{2} \mathrm{X}_{2}+\varepsilon_{\mathrm{i}}\right)\right]\right\}$

$\mathrm{P}(\mathrm{Y})=1 /\left\{1+\exp \left[-\left(\beta_{\mathrm{o}}+\beta_{3} \mathrm{X}_{3}+\varepsilon_{\mathrm{i}}\right)\right]\right\}$

Description:

$\beta_{\mathrm{o}}=$ intercept

$\beta_{\text {I }}=$ slope coefficient

$\mathrm{X} 1=$ total assets

$\mathrm{X}_{2}=$ capital structure of the company

$\mathrm{X}_{3}=$ bonus managers

$\mathrm{Y}=$ accounting methods

$\varepsilon_{\mathrm{I}}=$ disturbance or error term of population

\section{RESULT AND DISCUSSION}

\subsection{Overview of Research Objects}

In 1987, the Jakarta Stock Exchange (now the Indonesia Stock Exchange) was established. In 1987, there were only 24 listed companies selling their shares on the Jakarta Stock Exchange. In the last 30 years, the Indonesian 
Stock Exchange has developed quite rapidly, this can be seen from the number of companies that listed on the IDX to sell their shares and by the end of 2018 the listed companies were 633 companies.

From the 633 companies listed on the IDX, there are 164 companies that are classified as manufacturing companies and Chosen to be samples 127 companies.

\subsection{Analysis on the Influence of Total Assets, DER and Bonus Manager to Accounting Methods}

Testing the influence of independent variables on the accounting method for 127 companies were used Multiple Logistic Regression Analysis.

In initial step, the autocorrelation test will be performed using the Durbin Watson-test, collinearity testing using the coefficient of determination R2, and heteroscedasticity testing using the co-variance matrix.

Based on the test results of the data 127 companies, it can be stated that there is no significant autocorrelation, because the Durbin Watson test value is close to 2 (see Appendix-20) namely; D-W $=2,017$. It is also known that there is no collinearity of the relationship between the independent variable and the dependent variable, because the adjusted R2 value is 0.641 which means that it is quite high and which shows that many independent variables individually have an influence on the dependent variable. Noting the results of the tests above, the data analysis can be continued.

a) The first hypothesis testing is to determine the influence of independent variables on the accounting method

(Y). From the calculation results, the estimation of the Multiple Logistic Regression equation is obtained (see Appendix-4) as follows:

Accounting Method $(\mathrm{Y})=0.180+0.000 \mathrm{X}_{1}+0.685 \mathrm{X}_{2}+2.121 \mathrm{X}_{3}$

The results of calculating of the logistical influences of the independent variables individually on the selection of the Accounting Method P (Y) can be seen in the following;

Table.4-1. Magnitude of the Influence of Logistics Independent variables on the Selection of Accounting Methods $(\mathrm{Y})$ in the Summary Model.

Model Summary

\begin{tabular}{|l|r|r|r|}
\hline Step & -2 Log likelihood & Cox \& Snell R Square & Nagel kerke R Square \\
\hline 1 & $653,163^{\mathrm{a}}$ &, 403 &, 602 \\
\hline
\end{tabular}

a. Constant is included in the model.

b. The cut value is , 500

Table.4-2. The Significance of Logistic Influences of Independent Variables on the Selection of Accounting Methods (Y) in Variables in The Equation.

Variables in the Equation

\begin{tabular}{|c|c|c|c|c|c|c|c|}
\hline & B & S.E. & Wald & $\mathrm{df}$ & Sig. & $\operatorname{Exp}(B)$ \\
\hline \multirow[t]{4}{*}{ Step $1^{\mathrm{a}}$} & $\mathrm{X}_{1}$ & 000 & ,000 & 559, & 1 & ,384 & 1,000 \\
\hline & $X_{2}$ & ,685 & ,079 & 2,203 & 1 &, 032 & ,422 \\
\hline & $X_{3}$ & 2,121 & ,355 & 27,116 & 1 & ,000 & ,013 \\
\hline & Constant & 0,180 & 609 & 31,006 & 1 &, 000 & 43,059 \\
\hline
\end{tabular}

Based on table 4-1 above, it can be concluded that the influence of the independent variables simultaneously on the selection of accounting methods $(\mathrm{Y})$ is as follows:

Total Assets of the companies $\left(\mathrm{X}_{1}\right)$, DER (Debt to Equity Ratio) $\left(\mathrm{X}_{2}\right)$, and Bonus managers $\left(\mathrm{X}_{3}\right)$ have a significant influence on the selection of Accounting Methods (Y) which increases company earnings reporting. This is supported by Nagel R Square 0.602 or it can be interpreted that the model can influence the variation of changes in the selection of accounting methods by $60,20 \%$ and the remaining $39,80 \%$ variation in changes in the selection of accounting methods that have a tendency to increase profits determined by other variables not included in this model.

Based on table 4-2 above, it can be concluded that the influence of partially independent variables on the selection of accounting methods $(\mathrm{Y})$ is as follows:

Total Assets of the companies $\left(\mathrm{X}_{1}\right)$ do not have a significant influence on the selection of Accounting Methods (Y).

Debt of the companies or represented by DER (Debt to Equity Ratio) $\left(\mathrm{X}_{2}\right)$ has a significant influence on the selection of Accounting Methods (Y). This is supported by a significance level of $0.032<0.05$ or strengthened by the Wald test value of 2,203>2. This means that the greater the company's debt the greater the tendency to select accounting methods that increase company earnings reporting.

The companies that have a bonus plan for their managers $\left(\mathrm{X}_{3}\right)$ have a significant influence on the selection of the Accounting Method (Y), because the Wald test value is $27,116>2$ or P-value $0.00<$ alpha 0.05 . This 
means that the greater the bonus manager of the company will be more likely to select accounting methods that increase company earnings reporting.

\section{CONCLUSION AND SUGGESTION}

\subsection{Conclusion}

(1) Total Assets of the companies, Debt to Equity Ratio, and Bonus managers simultaneously have a significant influence on the selection of Accounting Methods. This is supported by Nagel R Square 0.602, or it can be interpreted that the model can influence the variation of changes in the selection of accounting methods by $60,20 \%$, and the remaining of $39,80 \%$ variation in changes in the selection of accounting methods that determined by other variables not included in this model.

(2) Total Assets of the companies do not have a significant influence on the selection of Accounting Methods.

(3) Debt of the companies or represented by Debt to Equity Ratio has a significant influence on the selection of Accounting Methods. This is supported by the significance level of $0.03<0.05$ or strengthened by the Wald test value of $2,203>2$. This means that the greater the company's debt, the greater the tendency to select accounting methods that increase corporate earnings reporting.

(4) The companies that have a bonus plan for their managers have a significant influence on the selection of the Accounting Methods, because the Wald test value is $27,116>2$ or p-value $0.00<$ alpha 0.05 . This means that the greater the bonus manager of the company, the greater the tendency to select accounting methods that increase company earnings reporting.

\subsection{Suggestion}

(1) Factors that influence the selection of the accounting method are debt or long-term debt ratio to owner equity and bonus managers. Its meant that; part of hypothesis of these research is corrected.

(2) Understanding the factors influencing the selection of accounting methods is carried out by having to pay attention to whether there is a change (up or down) in the value or unit of measure of the variable and pay attention to the causal relationship, namely whether a positive or negative relationship to the selection of accounting methods.

\section{References}

Amah Kalu Ogbonnaya Amauwa Basil.,"C Effect of Financial Reporting Quality on Financial Performance"., RJFA, Vol.10.No.11. 2019.

Ayitenew Temesgen and Lakech Estifanos "Determinants of Internal Audit Effectiveness: Evidence from Gurage Zone"., Research Journal of Finance and Accounting. 2018.

Atkinson, Anthony A., Rajiv D. Banker., Robert S. Kaplan., and S. Mark Young., "Management Accounting"., Second Edition, New Jersey; Prentice-Hall International, Inc. 2018.

Diamond, Michael A.,"Financial Accounting"., Third Edition, Cincinnati; College Division. South-Western Publishing Co, 1993.

Foster, George., "Financial Statement Analysis"., Second Edition. New Jersey; Prentice-Hall International Editions, 1986., h.134, h.135

Godwin et.all “Determinant of Audit Quality of Quoted Industrial Goods Sector in Nigeria”., Research Journal of Finance and Accounting. 2018.

Gujarati, Damodar N., "Basic Econometrics", Second Edition. New York: McGraw-hill International Edition. 1988.

IAI., "Standar Akuntansi Keuangan". Edisi Ikatan Akuntan Indonesia, 2018

Jensen, Michael.C and William.H. Meckling, "Theory of the Firm: Managerial Behavior, Agency Costs and Ownership Structure", Journal of Financial Economics. Volume 3 (October 1976).

Joyce, William B. "Managerial Compensation and the Provision for Loan Losses (Agency Theory)". Dissertation, 2018.

Kaplan, Robert S and Anthony A.Atkinson., “Advanced Management Accounting”., Second Edition. New Jersey; Prentice-Hall International Editions, 1989.

Kleinbaum, David. G., "Logistic Regression: A Self-Learning Text”., New York; Springer-Verlag New York Inc., 1994.

Mohammad Dabaghie., "The Impact of Accounting Disclosure Levels on Improving theMental Image of Pharmaceutical Companies in Jordan"., RJFA, Vol.10.No.8. 2019.

Nur eny Lolo and Muh. Rum.,'Environmental Green Accounting and Auditing Practice".'RJFA, Vol.10.No.08.,2019.

Robbins, Stephen P., “Organizational Behavior: Concepts, Controversies, and Applications., Seventh Edition. San Diego; Prentice-Hall International, Inc. 2016.

Schroeder, Richard.G., Myrtle Clark, and Levis D. Mc.Cullers., “Accounting Theory: Text and Readings”. Fourth 
Edition, New York: John Wiley and Sons. 1991.

Smith, Jay. M and K. Fred Skousen., "Intermediate Accounting”., Eleventh Edition, Cincinnati; College Division. South-Western Publishing Co, 1992.

Temesgen A Birhan "Determinants of turnover Tax Collection Effectivnes: The Case of West Gojiam"., Research Journal of Finance and Accounting. 2018.

Wolk, Harry.I., Jere.R. Francis, and Michael G. Tearney., “Accounting Theory: A Conceptual and Institutional Approcah", 5th Edition, Boston: PWS-KENT Publishing Company. 2015.

Watt, Ross L and Jerold L Zimmerman., "Positive Accounting Theory: A Ten Year Perspective"., The Accounting Review. Volume 65. No.1. January 1990.

William Smart Inyang, John Ogenyi Oboh, and Rex Tobechukwu Nwabuikem.,"Ethical Thoughts in Accounting And Their Effects On Accounting Practice”. RJFA, Vol.10.No.06.,2019.

Author: Afrizal (D’04-D'08--CH '15--'19). Dean of Economics Faculty of Jambi University (2004-2008), Dean of Economics Faculty of Jambi University (2008-2012), Chairman of Indonesia Accountants Institute for Jambi Province (2015-2019). Birth: 27 July 1959 Bukittinggi, Indonesia. Education: Bachelor in Accounting at Andalas University, Padang, Indonesia. Master in Accounting 1996 at Padjadjaran University, Bandung, Indonesia. Doctor in Accounting 1999 at Padjadjaran University, Bandung, Indonesia. 